\title{
A 60th anniversary
}

\begin{abstract}
The Council have therefore felt it a duty to publish a monthly journal which will be known as The Annals of the Royal College of Surgeons of England. It is hoped that The Annals will keep Fellows and Members of the College throughout the world conversant with recent advances in Surgery, with ex cathedra statements on various surgical subjects, and with the affairs of the College.
\end{abstract}

So wrote the then president of the College, Sir Alfred Webb-Johnson in 1947. The Annals, which initially included the Bulletin, is 60 years old and the aspirations of Sir Alfred and the Council of the time still hold today. The Annals and Bulletin are now produced separately. However, Bill Thomas (editor of the Bulletin) and I work closely to ensure that Sir Alfred Webb-Johnson's initial desires for the Annals are fully met.

Sir Alfred Webb-Johnson wrote a foreword to the first issue of the Annals and this is published in full in this issue. It makes interesting reading. The second world war had inflicted damage on the College and details of planned renovation and developments are presented. One comment of particular interest relates to the surgical specialties:

....representatives have been invited to attend the meetings of the Council. By Royal Charter authority has now been given to co-opt additional Members of the Council to be representatives of branches of practice not represented on the Council by the ordinary process of election.

This important statement is fundamental to the present Council's strategy agenda. Representatives of all nine surgical specialty associations have sat on Council for many years but detailed discussions are now taking place designed to ensure that the surgical specialties enjoy an even greater degree of 'embedding' within the College structure.

Other highlights of the 1947 volume include:

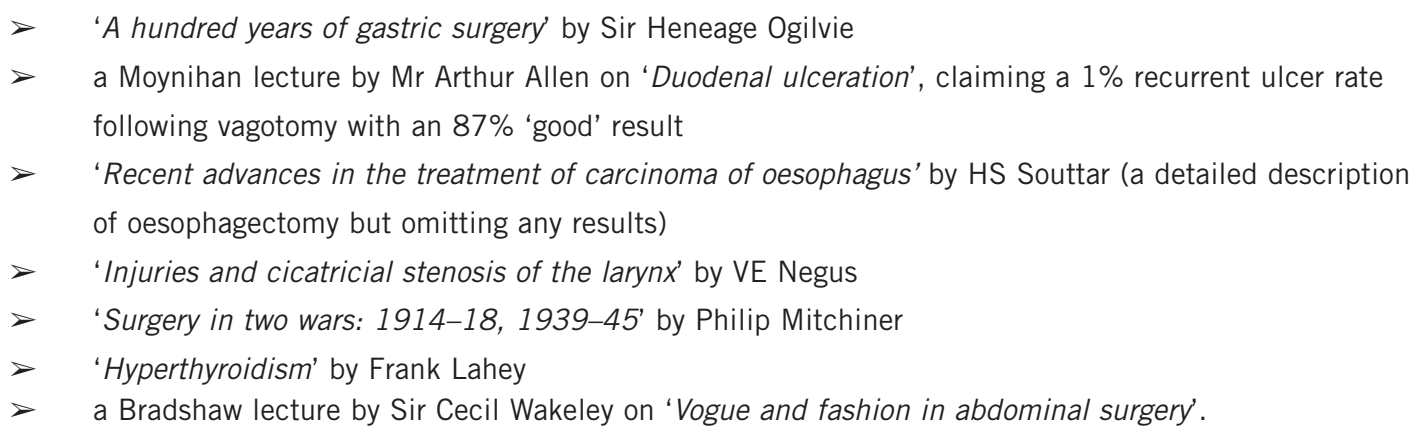

There have been six editors of the Annals: Sir Cecil Wakeley, Professor Harding Rains, Professor Jerry Kirk, Sir Barry Jackson, Professor John Lumley and myself. Bill Thomas has edited the Bulletin over the last two years.

I wish to thank my predecessors as editors of the Annals for ensuring continuity and quality in line with Sir Alfred Webb-Johnson's desires. I will certainly attempt to maintain this strong tradition.

During 2006, it became rapidly apparent that, in order to accommodate the huge increase in manuscript flow, the number of issues of the Annals would need to be increased. This proposal was approved by Council and there are now eight (rather than six) issues per year.

There has been a huge increase in the number of manuscripts submitted to the Annals from just over 600 in 2003 to almost 1000 in 2006 . The rejection rate remains at approximately $80 \%$. I am pleased to report that the time from acceptance of an article to its publication is now 7 months rather than an unacceptable 12 months, which we faced before the increase in number of issues.

Online usage has grown a great deal since the Annals became available via Ingenta in 2002. We now receive around 20,000 hits per month (compared to 8000 hits in January 2005). In fact, the Annals was ranked 76th out of 10,000 e-publications hosted on Ingenta, based on full-text downloads. 
Furthermore, online-only case reports, which were previously published as stand-alone 'supplementary data' are now processed together with the print issues of the Annals. This means they can be cited in PubMed, thus giving them the same prestige as printed articles.

The Annals is also available online through the Health InterNetwork Access to Research Initiative (HINARI) to local, not-for-profit institutions in developing countries. Set up by the World Health Organization, HINARI provides free or very low-cost access to almost 3500 major health-related journals at health institutions in over 100 countries, benefiting many thousands of health workers and researchers and, in turn, contributing to improved world health.

I am delighted to report that as a result of funding from the Wellcome Trust, the Joint Information Systems Committee and PubMed all back issues of the Annals will be available online from early 2007. Readers interested in articles from 1947 onwards can download these through PubMed. I regard this as a particularly valuable historical record and I hope members and fellows will make full use of this service.

My major responsibility as editor is to provide members and fellows with a clinical, practical and technical surgical journal. The Annals is not a vehicle for publishing high-powered, 'cutting-edge' scientific and research articles. Accordingly, it will not be a popular journal among university deans and vice-chancellors who regard the impact factor as the only measure of importance for an article. Rather, the Annals is a journal to inform readers of the range of technical innovation, audit and practice in the full spectrum of surgical endeavour. I remain anxious also to provide a forum for colleagues (both young and old) to reflect on their practice and activity as part of their professional and personal development. There is no doubt that we can all learn from developments in other surgical fields and benefit from practical tips.

Interestingly, a recently published, independently conducted survey of surgeons in the UK showed that the Annals was the second most read journal across all the surgical specialties. Over $60 \%$ of surgeons surveyed indicated that they read the Annals regularly. ${ }^{1}$

I would like to thank the entire editorial board for their assistance and support over the last year. I wish to record my particular gratitude to Colin Johnson (review editor), Tom Dehn (controversial topics), Bruce Campbell (NICE and technical tips), Linda de Cossart (regional meetings) and John Lowry (book reviews).

I am also most grateful to the hugely efficient publication team. David Atkins, Annals manager, left during the year and his role has been expertly undertaken by Tara Nikovskis. Hannah Chinery provides an outstanding and efficient service on a day-to-day basis as publication assistant. I wish also to thank our excellent production editors, Gill and Bruce Haddock.

Finally, I wish all our readers, members and fellows a very happy, healthy and productive New Year.

Irving Taylor

Editor-in-Chief, Annals

\section{Reference}

1. Jones TH, Hanney S, Buxton MJ. The journals of importance to UK clinicians: a questionnaire survey of surgeons.

BMC Med Inform Decis Mak 2006; 6: 24. 